\title{
PENGEMBANGAN E-LEARNING MENGGUNAKAN MOODLE DI UNIVERSITAS ISLAM LAMONGAN
}

\author{
M. Ghofar Rohman ${ }^{1}$, Munif ${ }^{2}$ \\ ${ }^{1,2)}$ Teknik Informatika, Fakultas Teknik, Unoversitas Islam Lamongan \\ Jl. Veteran No 53 A Lamongan \\ E-mail: m.ghofarrohman@unisla.ac.id ${ }^{l)}$.munif@unisla.ac.id ${ }^{2}$
}

\begin{abstract}
ABSTRAKS
Penelitian ini bertujuan untuk menghasilkan sistem pembelajaran berbasis website (e-learning) yang digunakan untuk pembelajaran daring di Universitas Islam Lamongan. Pada sistem pembelajaran daring ini ada 3 user; admin, dosen dan mahasiswa, admin sebagai pengendali utama aplikasi, dosen sebagai pengelola materi perkuliahan, tugas, quiz dan nilai, sedangkan mahasiswa dapat melihat materiperkuliahan untuk dipelajari, mengerjakan tugas, mengerjakan quiz, dan melihat nilai yang didapatkan. Pembelajaran daring di Universitas Islam Lamongan dilakukan dilaksanakan secara belended learning, dimana pembelajaran dilakukan dengan variasi antara pembelajaran daring dan tatap muka, untuk saling melengkapi kekurangan pada masing-masing pembelajaran. Pengembangan aplikasi pembelajaran daring di Universittas Islam Lamongan kedepanya perlu adanya pengembangan infrastruktur jaringan komputer, kemampuan dosen dalam menggunakan e-learning maupun dalam membuat isi (materi) pembelajaran daring, juga perlu adanya sesialisasi kepada mahasiswa mengenai penggunaan e-learning, dan adanya diseminasi tentang kebijakan pembelajaran daring pada sivitas akademika, sehingga dapat saling mendukung untuk peningkatan kualitas pembelajaran di Universitas Islam Lamongan.
\end{abstract}

Kata Kunci: e-learning, moodle, universitas islam lamongan.

\begin{abstract}
This reasearch aims to produce a website-based learning system (e-learning) that is used for online learning at the Lamongan Islamic University.In this online learning system there are 3 users; admin, lecturer and student, admin as the main controller of the application, lecturer as a manager of lecture material, assignments, quizzes and grades, while students can view lecture material for later study, work on assignments, work on quizzes, and see the grades obtained.Online learning at the Lamongan Islamic University is carried out in belended learning, where learning is carried out with variations between online learning and face-to-face, to complement each other's deficiencies in learning. Development of online learning applications in the Lamongan Islamic University in the future there is a need for the development of computer network infrastructure, the ability of lecturers to use e-learning and in creating online learning content (material), also the need for student socialization regarding the use of e-learning, and the existence of dissemination of policies online learning in the academic community, so that they can support each other to improve the quality of learning at the Lamongan Islamic University.
\end{abstract}

Keywords: e-learning, moodle, lamongan Islamic university.

\section{PENDAHULUAN}

\subsection{Latar Belakang}

Perkembangan yang terjadi di dunia pendidikan, khususnya di pendidikan tinggi berperan terhadap peningkatan kualitas lulusan yang harus mampu bersaing di era abad 21 ini. Saat ini dengan persaingan yang begitu ketat menuntut perguruan tinggi untuk dapat menghasilkan lulusan yang memiliki kualitas kompetitif serta lulusan yang mampu bertahan hidup dalam menyelesaikan permasalahan-permasalahan yang dihadapi dalam kehidupannya.

Perkembangan pola belajar masyarakat yang begitu cepat perubahannya harus menjadi dasar dalam perubahan yang terjadi di dunia pendidikan tinggi. Selain itu, perkembangan yang sangat pesat dalam ilmu pengetahuan dan teknologi juga membawa dampak pada perubahan secara signifikan terhadap model pembelajaran pada perguruan tinggi, sehingga pemanfaatan teknologi informasi dan komunikasi dalam pembelajaran akan mampu meningkatkan kualitas pembelajaran dan juga menghasilkan output perguruan tinggi yang mempunyai keterampilan yang mampu bersaing di dunia industri.

Tidak dapat dipumgkiri bahwa pemanfaatan teknologi informasi dan komunikasi dalam pembelajaran mampu meningkatkan kualitas pelayanan akademik dan mengatasi keterbatasan pembelajaran di kelas (tatap muka). Menyadari akan hal itu, pimpinan Universitas Islam Lamongan mempunyai kebijakan untuk mengembangkan sistem pembelajaran daring (e-learning) yang dalam dikembangkan menggunakan aplikasi Modular 
Object-Oriented Dynamic Learning Environment (Moodle). E-learning tersebut dipasang pada server Universitas Islam Lamongan dan semua civitas akademika dapat mengakses menggunakan akun yang telah disediakan oleh administrator.

Pemanfaatkan aplikasi Moodle sebagai bentuk dari pemanfaatan teknologi informasi dalam pembelajaran di Universitas Islam Lamongan untuk menerapkan konsep pembelajaran daring. Aplikasi ini dapat dengan mudah ditemukan dan di download di internet, aplikasi ini dibuat untuk kegiatan pembelajaran dengan memanfaatkan jaringan internet melalui situs web yang dibangun khusus dan dapat membantu pengajar didalam proses pembelajaran dari segala sudut pandang, dimana tidak hanya melakukan publikasi informasi tetapi dapat menuangkan segala pemikiran yang akan dituangkan seperti diskusi, tugas, quiz dan penilaian.

Aplikasi ini dapat membantu dosen untuk memantau partisipasi mahasiswa dalam kegiatan pembelajaran, dimana mahasiswa dapat saling berinteraksi antara satu sama lain bahkan dengan para dosen mata kuliah tersebut. Moodle tidak memaksa dosen merubah gaya mengajarnya, tetapi pengembangan aplikasi e-learning ini seharusnya dapat mendukung pembelajaran yang dilakukan oleh dosen.

\subsection{Rumusan Masalah}

Rumusan masalah pada penelitian ini antara lain:

1. Bagaimana merancang pembelajaran daring sehingga dapat membantu proses pembelajaran?

2. Bagaimana mengimplementasikan pembelajaran daring berbasis Moodle di Universitas Islam Lamongan?

\subsection{Tujuan Penelitian}

Tujuan dari penelitian yaitu merancang sistem pembelajaran berbasis website yang digunakan untuk pembelajaran daring di Universitas Islam Lamongan.

\subsection{Landasan Teori}

\section{a. Media Pembelajaran}

Menurut Susilo dan Rohman (2019) media pembelajaran merupakan komponen yang cukup penting dalam pelaksanaan sistem pembelajaran. Hal ini dikarenakan tanpa adanya sebuah media, maka upaya komunikasi tidak akan tercipta dan proses pembelajaran tidak dapat berjalan secara optimal karena media pembelajaran merupakan bagian komponen yang tidak terpisahkan dalam sistem pembelajaran.

Media pembelajaran merupakan alat bantu yang dipergunakan pendidik untuk menyampaikan materi pelajaran kepada peserta didik dan memegang peranan penting dalam dunia pendidikan (Widodo dan Wahyudin, 2018). Media pembelajaran bisa dibuat secara manual maupun dengan bantuan software atau aplikasi berbasis website. Salah satu software yang dapat digunakan adalah Moodle.

\section{b. E-Learning}

Menurut Munir (2010) e-learning adalah kegiatan pembelajaran yang dilaksanakan dengan menggunakan bantuan media atau jasa perangkat elektronika, dalam pelaksanaanya e-learning merupakan kegiatan pembelajaran yang dilaksanakan melalui jaringan komputer. Sehingga hal ini memungkinkan tersampaikanya bahan ajar melalui media teknologi informasi kepada mahasiswa, dengan menggunakan e-learning, belajar dapat dilaksanakan kapan saja, dimana saja, melalui jalur mana saja, dan dengan kecepatan akses apapun.

\section{c. Arsitektur Pembelajaran pada E-learning}

Dalam prakteknya e-learning memerlukan bantuan teknologi. Karena itu dikenal istilah: computer based learning (CBL) yaitu pembelajaran yang sepenuhnya menggunakan komputer dalam kegitan pembebelajaran; dan computer assisted learning (CAL) yaitu pembelajaran yang menggunakan alat bantu utama komputer dalam pembelajaran (Rusman; 2013).

Dengan demikian, e-learning adalah pembelajaran yang pelaksanaannya didukung oleh bantuan perangkat elektronik, seperti komputer, smartphone, audio, videotape, atau jaringan. Penggunaan teknologi informasi dan komputer pada e-learning dapat menjadi keunggulan dan sekaligus tantangan bagi penyelenggara e-learning.

Henderson dalam Hardyanto dan Surjono (2016), menyatakan bahwa ada 3 macam tipe pembelajaran yang dilakukan dengan menggunakan e-learning: Pertama, Synchronous, yaitu sekelompok mahasiswa bertemu dengan instruktur melalui internet, dimana user online pada waktu yang sama ketika mereka berkomunikasi satu dengan yang lain, instruktur dapat berinteraksi dengan siswa, siswa dapat berinteraksi dengan siswa lain; kedua, Self-direct, yaitu siswa bertindak sendiri untuk belajar, tidak ada guru/instruktur, teman yang berinteraksi dengannya; dan yang ketiga Asynchronous, gaya belajar ini merupakan gaya belajar kolaboratif, sekelompok siswa bertemu dengan guru melaui internet dan dapat berkomunikasi, namun tidak selalu online pada waktu yang sama. Siswa dapat berkomunikasi dengan meninggalkan pesan yang dapat direspon selang beberapa waktu.

\section{d. Blended Learning}

Kegiatan belajar mengajar pada model pembelajaran blended learning adalah hasil dari kombinasi antara pembelajaran daring dengan pembelajaran tatap muka di kelas atau di laboratorium. Dimana pada pembelajaran blended learning sebagian besar materi disampaikan melalui daring dan sebagian lagi melalui tatap muka. Tujuan 
dari diimplementasikanya model pembelajaran blended learning ini adalah untuk mengatasi keterbatasan-keterbatasan yang terdapat pada pembelajaran tatap muka yang dilengkapi melalui pembelajaran daring, dalam hal ini dengan menggunakan e-learning, dan sebaliknya juga untuk mengatasi kesulitan pelajar dalam belajar melalui elearning dapat dilengkapi dengan pembelajaran tatap muka.

Dalam model pembelajaran blended learning dosen dapat memberikan petunjuk pada mahasiswa untuk mempelajari materi perkuliahan yang telah di diunggah pada website (e-learning) yang telah disediakan, dosen dapat mengakses e-learning dan mengunggah materi perkuliahan melalui akun sebagai dosen. Sedangkan mahasiswa juga diberikan arahan untuk mencari sumber lain dari situs dan sumber belajar yang relevan dengan materi perkuliahan. Dalam pembelajaran tatap muka, kegiatan dosen dan mahasiswa lebih banyak diskusi mengenai temuan-temuan materi yang telah dipelajari melalui e-learning, yang mana mahasiswa diharapkan akan lebih aktif untuk berdiskusi.

\section{e. Moodle}

Moodle merupakan salah satu aplikasi dari konsep dan mekanisme pembelajaran yang memanfaatkan teknologi informasi dan komunikasi yang lebih dikenal dengan konsep pembelajaran elektronik (e-learning). Moodle dapat digunakan secara bebas sebagai produk open source dibawah lisensi GNU. Moodle dapat diinstal di komputer dan sistem operasi apapun yang bisa menjalankan PHP dan mendukung database SQL.

Moodle lebih dikenal fungsinya sebagai Course Management System atau Learning Management System (LMS). Dengan tampilan seperti halaman web pada umumnya, moodle memiliki fitur untuk menyajikan kursus (course), dimana pengajar dapat mengunggah materi ajar, soal dan tugas. Peserta didik pun dapat login ke moodle kemudian memilih course yang disediakan untuknya. Aktivitas peserta didik dalam moodle dapat terpantau progress dan nilainya.

\section{PEMBAHASAN}

\subsection{Metode Penelitian}

Adapun metode penelitian atau desain penelitian yang digunakan adalah metode penelitian dan pengembangan (Research and Development). Peneliti bermaksud membuat sistem e-learning yang diharapkan dapat berjalan secara efektif dalam meningkatkan mutu pendidikan di Universitas Islam Lamongan.

\subsection{Perancangan Sistem}

Berikut perancangan sistem e-learning pada penelitian ini:

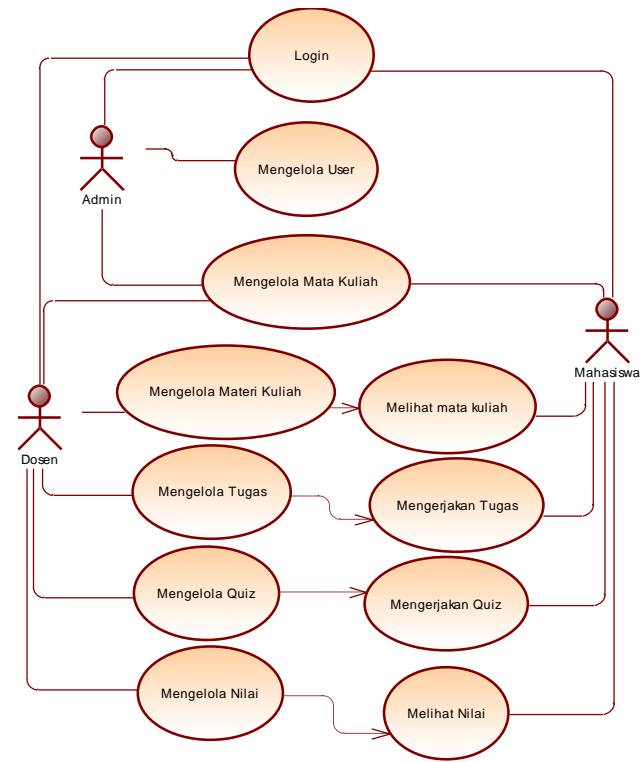

Gambar 2.1 Use Case Diagram e-learning

Pada sistem pembelajaran ini terdapat tiga user, yaitu: pertama Admin sebagai pengelola aplikasi, yang dapat mengelola user dan mengelola mata kuliah, kedua adalah Dosen yang mempunyai fungsi untuk mengelola materi perkuliahan, tigas, quiz dan penilaian. Dan ketiga Mahasiswa yang mempunyai fungsi untuk mempelajari materi perkuliahan yang diunggah oleh dosen, tugas, quiz dan melihat nilai.

\subsection{Uji Coba Sistem}

Sebelum sistem dipublikasikan, terlebih dahulu dilakukan beberapa pengujian untuk memastikan sistem dapat berjalan dengan baik.

Bagian-bagian sistem yang dilakukan pengujian antara lain :

\section{a. Kecepatan akses}

Dalam pengukuran kecepatan akses pada media penyimpanan atau server, pengujian pada tahap ini dilakukan dengan membandingkan kecepatan akses melalui jaringan komputer lokal (localhost), dan jaringan Internet dengan menggunakan beberapa web browser dan hasilnya menunjukkan bahwa sistem dapat berjalan dengan baik pada setiap browser.

\section{b. Struktur Link pada sistem e-leaning}

Struktur link perlu diuji untuk menghindari kemungkinan adanya link-link yang terputus akibat berpindahnya lokasi link tujuan, berubahnya nama file yang dituju, terhapusnya link tujuan ataupun karena sebab lain. Pengujian dilakukan dengan melakukan pemeriksaan satu persatu setiap menu yang menghubungkan antara halaman satu dengan dengan halaman lain. Dari pengujian ini menunjukkan bahwa link yang terdapat pada sistem 
dapat berjalan dengan baik sesuai dengan fungsi masing-masing.

c. Kompatibilitas browser yang digunakan

Pada tahap pengujian ini menguji kompatibilitas browser terhadap aplikasi pembelajaran daring, uji coba dilakukan dengan menggunakan beberapa web browser di antaranya Internet Explorer, Mozilla Firefox dan Google Crome. Hasilnya uji coba menyatakan bahwa secara garis besar tidak ada perbedaan yang mendasar dan signifikan dari hasil pengujian tersebut dan menunjukkan bahwa sistem dapat berjalan dengan baik.

\subsection{Implementasi Program}
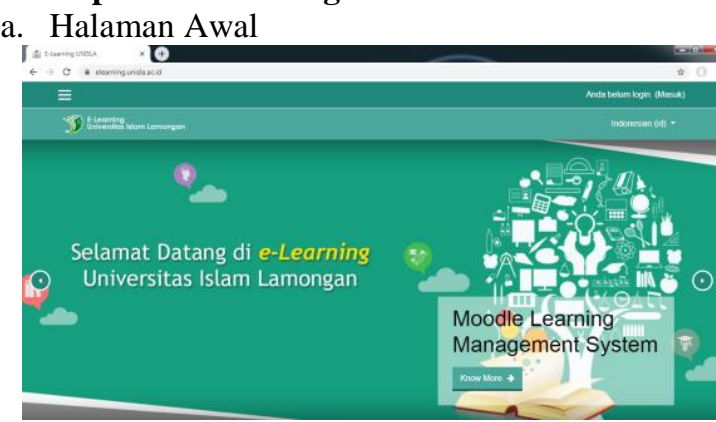

Gambar 2.2 Halaman awal e-learning.unisla.ac.id

Pada halaman awal berisi tentang tampilan awal aplikasi, menu logiin, dan informasi daftar mata kuliah yang sudah masuk di sistem pembelajaran daring.

b. Halaman Admin

Login Admin

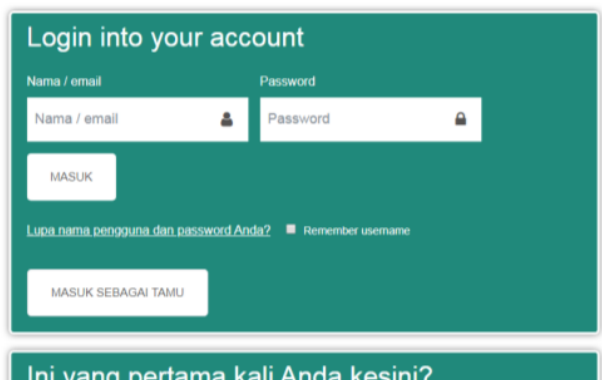

Gambar 2.3 Halaman Login

Pada halaman ini admin dapat melakukan login dengan menginputkan nama/email dan password, apabila sukses akan langsung masuk ke halaman admin, sedangkan kalau tidak sesuai (gagal) maka akan tetap pada halaman login. Apabila mengalami lupa password, dapat melakukan klik pada link "Lupa nama pengguna dan password anda?", untuk kemudian melakukan pengisian form sesuai dengan yang diajukan oleh sistem.

Halaman Admin

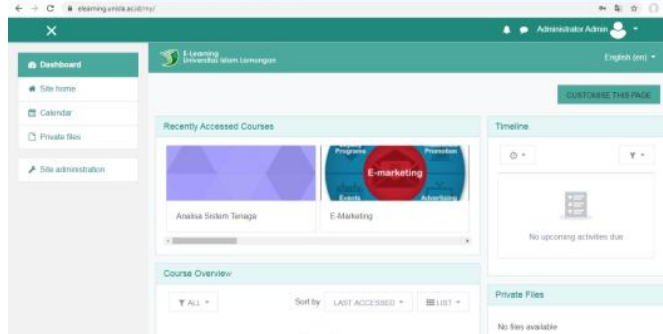

\section{Gambar 2.4 Halaman Awal Admin}

Pada halaman ini berisikan berbagai menu, diantaranya "custumize this page, site home, calender, site administration, timeline, course overview, recently acceessed courses, dan lain-lain". Untuk daftar mata kuliah yang diampu dapat dilihat pada menu "Recently Aceessed Courses".

c. Halaman Dosen

Login Dosen

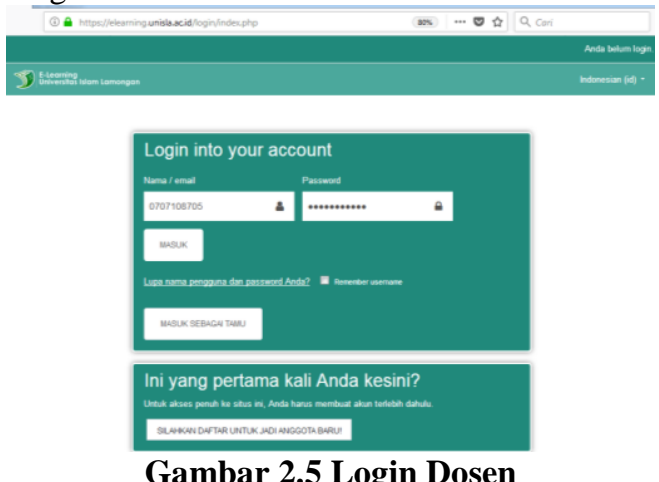

Untuk masuk ke halaman dosen terlebih dahulu harus melakukan login sebagai dosen, pada aplikasi ini dilakukan dengan menggunakan NIDN dan password yang telah didaftarkan sebelumnya. Apabila sesuai maka akan langsung masuk ke halaman awal dosen.

Profil Dosen
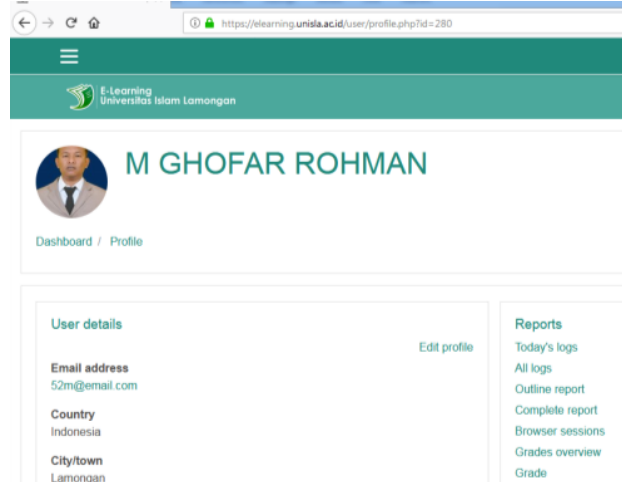

Gambar 2.6 Profil Dosen

Pada halaman profil dosen berisi tentang datadata pribadi dosen, seperti email, negara, kota, laporan-laporan (reports) dan lain-lain. Untuk melakukan edit profile dosen dapat dilakukan dengan mengaktifkan link "Edit profile". Pada menu 
report dapat melihat data log hari ini, semua $\log$, laporan outline, nilai, dan lain-lain.

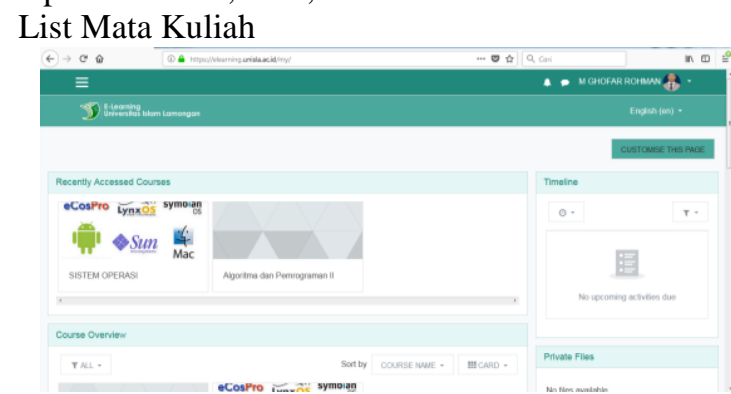

Gambar 2.7 Halaman List Mata Kuliah

Pada halaman ini Dosen dapat melihat mata kuliah yang diampu, setelah itu dapat memilih pada mata kuliah untuk meudian melakukan upload materi pembelajaranya.

d. Halaman Mahasiswa

Login Mahasiswa
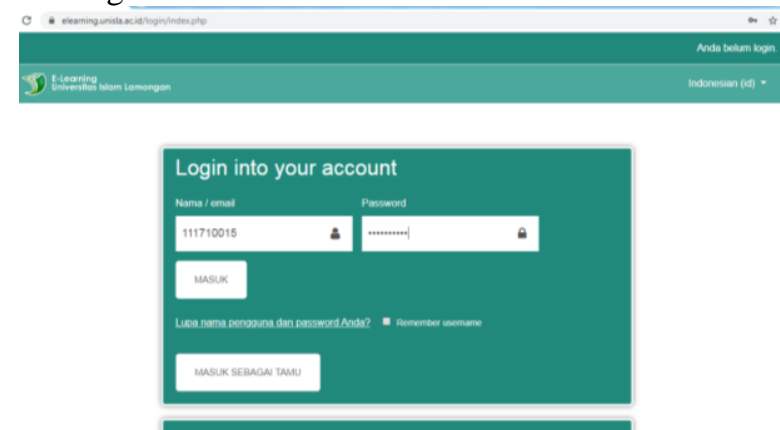

Gambar 2.8 Halaman Login Mahasiswa

Pada halaman login, dapat menggunakan NIM (Nomor Induk Mahasiswa) dan password sesuai dengan yang terdaftar. Sehingga secara otomatis akan masuk ke halaman mahasiswa apabila login berhasil.

\section{Daftar Mata Kuliah}

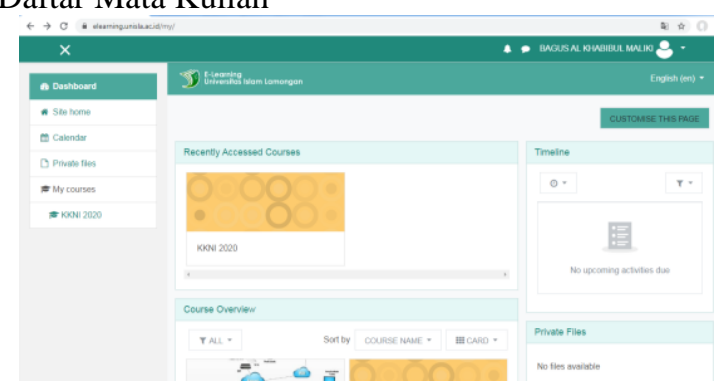

Gambar 2.9 Halaman awal Mahasiswa

Pada halaman ini berisi fitur-fitur yang disediakan untuk mahaasiswa, seperti daftar mata kuliah yang diambil mahasiswa terkait, profil mahasiswa, ganti password dan lain-lain. Untuk mengikuti perkuliahan, mahasiswa dapat mengaktifkan link mata kuliah pada menu list mata kuliah.

\subsection{Implementasi Pembelajaran daring di Universitas Islam Lamongan}

Implementasi e-learning di Universitas Islam Lamongan dapat diakses pada alamat website www.e-learning.unisla.ac.id. Sistem e-learning ini dikembangkan menggunakan Moodle, yang mana pada e-learning ini tedapat 3(tiga) akun user, yaitu Admin, Dosen, dan Mahasiswa.

Pemanfaatan e-learning berbasis moodle sebagai media pembelajaran di Universitas Islam Lamongan akan berdampak pada proses kegiatan pembelajaran yang tepat waktu tidak terdapat kendala yang disebabkan adanya batasan ruang dan waktu.

Kompetensi mahasiswa akan meningkat karena ini menjadi hal yang baru sehingga menjadikan wadah belajar bersama serta kegiatan pembelajaran itu sendiri. evaluasi yang dilaksanakan dosen untuk mahasiswa lebih tepat waktu sehingga menjadikan sebagai pedoman didalam membuat laporan evaluasi mahasiswa.

Sekalipun pembelajaran daring memungkinkan untuk dilakukan secara virtual penuh, namun kesempatan ini tidak dipilh untuk diimplementasikan di Universitas Islam Lamongan, sehingga yang diimplementasikan adalah sistem blended learning. hal ini dikarenakan interaksi antara mahasiswa degan dosen masih dibutuhkan untuk berkomunikasi secara langsung, baik untuk menjelaskan maksud dan mekanisme pembelajaran, mahasiswa perlu untuk saling mengenal pribadi satu dan lainya untk mendukung iklim partisipatoris dan aktif dalam pembelajaran, adanya kekurangan kemampuan dalam mengoperasikan pembelajaran daring yang akan berdampak pada minimnya partisipasi mahasiswa dalam pembelajaran.

Untuk pengembangan lebih lanjut tentang pemanfaatan e-learning berbasis lcms moodle sebagai media pembelajaran di Universitas Islam Lamongan; (a) perlu adanya pengembangan infrastruktur baik intranet maupun internet untuk mendukung kegiatan e-learning sehingga tidak ada kendala pada saat memanfaatkan e-learning. untuk mengoptimalkan kegiatan e-learning ini. (b) Perlu adanya pelatihan-pelatihan kepada dosen dalam penggunaan e-learning, maupun dalam membuat konten e-learning yang baik sehingga akan lebih banyak materi mata kuliah yang diunggah pada website pembelajaran daring Universitas Islam Lamongan. (c) perlu adanya sosialisasi secara berkelanjutan terkait pembelajaran daring kepada mahasiswa, sehingga dapat membuat mahasiswa semakin termotivasi untuk menggunakan pembelajaran daring. Dan (d) perlu adanya diseminasi-diseminasi tentang kebijakan-kebijakan pembelajaran daring kepada sivitas akademik Universitas Islam Lamongan.

\section{KESIMPULAN}

Bahwa aplikasi pembelajaran daring (e-learning) dengan menggunakan moodle ini dapat digunakan 
pada pembelajaran daring di Universitas Islam Lamongan dan hal ini selaras dengan dengan Kurikulum Berbasis KKNI yang di implementasikan di Universitas Islam Lamongan.

Moodle mempunyai banyak sekali fasilitas yang mendukung proses pembelajaran. Fasilitas-fasilitas pada moodle ini perlu untuk terus dieksplorasi dan dikembangkan dalam aplikasi pembelajaran daring, supaya dapat mendukung dalam peningkatan kualitas sistem pembelajaran di Universitas Islam Lamongan.

Dalam mengimplementasikan e-learning di Universitas Islam Lamongan, masih banyak mata kuliah yang belum terintegrasi atau belum terunggah di e-learning. Hal ini dikarenakan masih minimnya jumlah partisipasi dosen dalam pembelajaran daring, kurangnya sosialisasi kepada mahasiswa dan sivitas akademik lainya, serta perlu adanya pengembangan dalam sarana prasana pada layanan Internet (jaringan komputer).

\section{PUSTAKA}

Handoko, dan Waskito. 2018. Blended Learning Teori dan Penerapanya. Padang, Sumatera Barat. LPTIK Universitas Andalas.

Hardyanto, R. Hafid. dan Surjono, Herman Dwi .2016. Pengembangan Dan Implementasi $E$ Learning Menggunakan Moodle Dan Vicon Untuk Pelajaran Pemrograman Web di SMK. Jurnal Pendidikan Vokasi Volume 6, No 1, Februari 2016 (43-53)

Majid, Abdul. 2014. Strategi Pembelajaran. Bandung. PT Remaja Rosdakarya Offset.

Munir. 2010. Kurikulum Berbasis Teknologi Informasi dan Komunikasi. Bandung. CV. Alfabeta

Pradnyana, Gede Aditra dan Pradnyana, I Made Ardwi. 2015. Implementasi Responsive Elearning Berbasis MOODLE Untuk Menunjang Kegiatan Pembelajaran di STMIK STIKOM Indonesia. Jurnal S@CIES Volume 5, Nomor 2, April 2015, hlm 127-135

Rusman. 2013. Model-model Pembelajaran: Mengembangkan Professionalisme Guru (Edisi kedua). Jakarta. Rajawali Pers.

Susilo, Purnomo Hadi. dan Rohman, M. Ghofar. 2019. Sistem Pembelajaran Online Berbasis Aplikasi Web Menggunakan Framework Codeigniter. JOUTICA Volume 4 No.2 2019. ISSN: 2503-071X. E-ISSN: 2621-511X.

Widodo, Sri Adi. dan Wahyudin. 2018. Selection of Learning Media Mathematics for Junior School Students. TOJET: The Turkish Online Journal of Educational Technology - January 2018, volume 17 issue $1,154-160$. 